\title{
COLOR CHANGE AND QUALITY RESPONSE OF 'LANE LATE' ORANGE SUBMITTED TO DEGREENING PROCESS
}

Doi:http://dx.doi.org/10.1590/1809-4430-Eng.Agric.v35n 1p 144-153/2015

\section{FRANCISCA L. DE C. MACHADO ${ }^{1}$, JOÃO P. CAJAZEIRA ${ }^{2}$, JOSÉ M. C. DA COSTA ${ }^{3}$}

\begin{abstract}
This study aimed at evaluating the effects of ethylene on peel color and compositional changes in 'Lane late' orange stored under refrigerated and ambient conditions. Physiologically mature, but green-peeled, oranges were exposed to ethylene gas under room temperature and high relative humidity for 24 hours. Storage chamber was ventilated with fresh air after 12 hours to mitigate consequences derived from fruit respiration. Both nondestructive analysis, such as peel color (hue angle, chromaticity, and brightness) and weight loss, and destructive ones (soluble solids, titratable acidity, $\mathrm{pH}$, soluble solids to acidity ratio, and puncture force) were performed upon harvest, after degreening, and every three days during eighteen days in storage. Experiment was carried out using an entirely randomized design with thirty replications for nondestructive and four replications for destructive analyses, in a split plot scheme. Exposure to ethylene ensured a golden yellow peel for both fruit stored under ambient and refrigerated conditions. High relative humidity, associated with low temperature prevented fruit from losing moisture. Fruit exposure to ethylene did not affect weight loss, soluble solids, titratable acidity, $\mathrm{pH}$, soluble solids, acidity ratio, or puncture force.
\end{abstract}

KEYWORDS: Citrus sinensis (L.) Osbeck, Peel Color, Ethylene, Fruit Internal Quality.

\section{MUDANÇA NA COR E RESPOSTA NA QUALIDADE DE LARANJA 'LANE LATE' SUBMETIDA AO TRATAMENTO DE DESVERDECIMENTO}

\begin{abstract}
RESUMO: Este trabalho objetivou determinar o efeito da aplicação de etile no na cor da casca e em mudanças na composição da laranja 'Lane late' armazenada em condição ambiente e refrigerada. Laranjas fisiologicamente maduras, mas com casca verde, foram expostas ao gás etileno em temperatura ambiente e umidade relativa alta por 24 horas. A câmara foi ventilada com ar fresco após 12 horas de tratamento, com intuito de amenizar as consequências trazidas pelo processo respiratório dos frutos. As avaliações não destrutivas, cor da casca (ângulo de cor hue, cromaticidade e luminosidade) e perda de peso, bem como as destrutivas (sólidos solúveis, acidez titulável, $\mathrm{pH}$, razão entre sólidos solúveis e acidez, e força de perfuração da casca) foram realizadas logo após a colheita, após tratamento de desverdecimento e a cada três dias, por dezoito dias. O delineamento utilizado foi o inteiramente casualizado, em esquema de parcelas subdivididas, com 30 repetições (avaliações não destrutivas) e quatro repetições (avaliações destrutivas). Exposição dos frutos ao etileno as segurou cor da casca amarelo-ouro para frutos mantidos em condições ambiente e refrigerada. Umidade relativa alta, associada à refrigeração, evitou a perda de umidade dos frutos. Sólidos solúveis, acidez titulável, $\mathrm{pH}$, relação sólidos solúveis/acidez e força de penetração da casca não diferiram entre frutos tratados e não tratados.
\end{abstract}

PALAVRAS-CHAVE: Citrus sinensis (L.) Osbeck, cor da casca, etileno, qualidade interna.

\section{INTRODUCTION}

During the development citrus undergoes chemical changes, which are directly influenced by local climatic conditions, leading to changes in internal and external characteristics such as sugar

\footnotetext{
${ }^{1}$ Enga A grônoma, Profa. Doutora, Curso Técnico em Agricultura, IFCE /Tianguá - CE, Fone: (88) 36712299 , ligiacmachado@y ahoo.com

${ }^{2}$ Eng $^{\circ}$ A grônomo, Ms.C em Solos, Departamento de Solos, UFC/Fortaleza - CE, jp_caja@y ahoo.com.br

${ }^{3}$ Eng $^{\circ}$ de Alimentos, Prof. Doutor, Departamento de Tecnologia de Alimentos, UFC/Fortaleza - CE, correia@ufc.br Recebido pelo Conselho Editorial em: 14-2-2011 
level and peel coloring. Fruit color is controlled by several factors such as ripeness, plant nutrition, rootstock, crop practices, water availability, and climatic conditions. According to LIDANIYA (2008), in sub-tropical climates, citrus peel yellowing occurs when the nighttime temperature becomes lower than $12.8{ }^{\circ} \mathrm{C}$ and/ or soil temperature is below $12{ }^{\circ} \mathrm{C}$. Such condition, however, seldom occurs in tropical regions, where high temperatures and relative humidity are more common. Thus, fruit grown in tropical regions, such as Ceará State, Northeastern Brazil (5 $5^{\circ} 13^{\prime} S$, $\left.37^{\circ} 54^{\prime} \mathrm{E}\right)$, often reaches physiological maturity presenting excellent eating quality, while the peel remains green. Citrus green peel may not be an impediment for local market, since consumers do not associate peel color with internal quality; nonetheless, for export market, fruit must present a yellow shining peel. Therefore, exporting of local grown quality citrus requires the enhancement of peel color, which may be achieved by degreening treatments.

Degreening with ethylene is a common postharvest practice in citrus fruit (RODRIGO \& ZACARIAS, 2007). Ethylene, a naturally produced plant growth hormone, regulates several plant metabolic and growth processes. Ethylene has a particular economic importance as a fruit ripeness inducer; this is based on a sequence of biochemical events resulting in chlorophyll loss, forming pigments, flavors, aromas and pulp softening.

Although citrus is a non-climacteric fruit, due to the virtual absence of ethylene production and respiration rate increases during ripening (LIDANIYA, 2008); its exogenous application accelerates physiological and molecular responses, similar to those naturally induced during ripening (PORAT, 2008) such as peel color change. Ethylene promotes an increase in the activity of chlorophyllase and oxidase enzymes (RODRIGO \& ZACARIAS, 2007), which are responsible for chlorophyll degradation and green color disappearance, and stimulates carotenogenesis, which promotes yellowing or oranging of fruit peel (PORAT, 2008).

Degreening efficiency depends on various factors such as fruit cultivar, amount of exogenous ethylene applied, exposure time, and environment temperature. In Spain, citrus fruits are degreened at somewhat low temperatures (18 to $22{ }^{\circ} \mathrm{C}$ ) (TIETEL et al., 2010), while in Florida, U.E.A., citrus fruits are commercially degreened at relatively high temperatures as $29{ }^{\circ} \mathrm{C}$ (LIDANIYA, 2008). In Brazil, JACOMINO et al. (2003) recommended degreening of 'Sicilian' lemon cultivated in São Paulo State (22 26' 04' 'S, $4657^{\prime}$ E) to be held at $20^{\circ} \mathrm{C}$.

In previous study, MACHADO et al. (2010) did not succeed in degreening sweet orange cv. 'Navelina', grown in Ceará State $\left(5^{\circ} 13^{\prime} \mathrm{S} ; 37^{\circ} 54^{\prime} \mathrm{E}\right)$, Brazil, harvested ripe, but with green peel, when treatment was held at $22{ }^{\circ} \mathrm{C}$, showing the importance of the interaction between temperature and ethylene concentration on the degreening process. The objective of this study was to examine the effects of treatment with ethylene to promote degreening in sweet orange cv. 'Lane late' harvested at physiological maturity, but presenting green peel. The study examined also fruit quality response to degreening treatment during storage at ambient and refrigerated condition.

\section{MATERIAL AND METHODS}

\section{Plant material and sampling}

Fruits of sweet, seedless orange cv. 'Lane late' (Citrus sinensis L. Osbeck) were harvested in March 2010, from trees grafted on trifoliate orange (Ponciruis trifoliata) rootstock, from an wellmanaged orchard located in Limoeiro do Norte county ( $5^{\circ} 11^{\prime} 38^{\prime}$ S, 37 $52^{\prime} 21^{\prime}$ ' E), Ceará State, Brazil. After transport to the laboratory, fruits were selected for peel color uniformity (hue angle value $120 \pm 5)$, size $(90 \pm 5 \mathrm{~mm}$ diameter) and absence of external blemishes. Afterward, they were rinsed with tap water, air-dried, and divided into four experimental sets. These sets corresponded to the following treatments: degreening followed by ambient storage $\left(22 \pm 2{ }^{\circ} \mathrm{C}\right.$ and $\left.48-50 \% \mathrm{RH}\right)$, degreening followed by refrigerated storage $\left(7 \pm 1^{\circ} \mathrm{C}\right.$ and $\left.90-95 \% \mathrm{RH}\right)$, non-degreening followed by ambient storage $\left(22 \pm 2{ }^{\circ} \mathrm{C}\right.$ and $\left.45-50 \% \mathrm{RH}\right)$ and non-degreening followed by refrigerated storage $(7 \pm 1 \circ \mathrm{C}$ and $90-95 \% \mathrm{RH})$. For the measurements of color development and weight loss, thirty fruits per treatment were individually numbered and marked at the opposite sides within the equatorial region. For the remaining analyses, fruits were randomly selected from each set of treatments. All 
analyses were performed right before degreening treatment, in the morning following degreening, and every period of four days up to the eighteenth day in storage.

\section{Degreening treatment}

Fruits were placed in a well-insulated storage chamber at ambient condition $\left(28 \pm 2{ }^{\circ} \mathrm{C}\right.$ and $95 \% \mathrm{RH})$ containing a commercially available electric ethylene generator (Banasil@). A predetermined amount of ethyl concentrate was poured into the gas generator to produce ethylene gas at concentration of $10 \mu \mathrm{L} . \mathrm{L}^{-1}$. Fruits remained in contact with the ethylene gas for 24 hours in the dark. To avoid an excess of respiratory $\mathrm{CO}_{2}, \mathrm{Ca}(\mathrm{OH})_{2}$, the chamber was completely ventilated with fresh outside air after 12 hours of treatment. Control fruits were placed in an ethylene-free atmosphere and under the same temperature and humidity conditions as the treated ones. After treatment, degreened and non-degreened fruits were stored at both ambient $\left(22 \pm 2{ }^{\circ} \mathrm{C}\right.$ and $45-50 \%$ $\mathrm{RH})$ and refrigerated $\left(7 \pm 1^{\circ} \mathrm{C}\right.$ and $\left.90-95 \% \mathrm{RH}\right)$ conditions for 18 days.

\section{Color development analysis}

Color was accessed with a Minolta Chroma Meter CR-330 (Minolta Corporation Instrument Systems) calibrated to a white porcelain reference plate. The L, a* $b^{*}$ color values were scored from previously indicated positions on the opposite sides of the fruits. Results were expressed as hue angle, chromaticity, and brightness (McGUIRE, 1992).

\section{Loss of weight analysis}

Weight loss was determined by weighing each previously numbered fruit at harvest and during storage and then calculating weight loss by weight differences. Results were expressed as percentage of weight loss (\%).

\section{Quality parameters analysis}

Peel resistance to puncturing was assessed with a force gauge (model DD-200) fitted with a 5 $\mathrm{mm}$ cylindrical probe in the probe carrier. Fruit were placed upon a flat plate with the stem calyx axis parallel to the plate surface. Puncture resistance, expressed as N, was recorded as the maximum force required to puncturing the fruit peel.

In order to perform destructive analyses, juice was extracted from fruit halves with an automated squeezer with a rotating red; then, samples were filtered and homogenized before each analyze. Soluble solids were determined in juice samples with a digital refractometer (0-45 Brix) (Palette 100, Atago, Co., Ltd) and expressed as degree Brix. Acidity was determined by titration to endpoint ( $\mathrm{pH}$ 8.2) with $0.1 \mathrm{~N} \mathrm{NaOH}$, and expressed as mg of citric acid/ 100 g juice. The $\mathrm{pH}$ was measured with a pH-meter directly in the juice. The ratio between soluble solids and acidity was obtained by dividing soluble solids values by acidity ones.

\section{Statistical analysis}

An entirely randomized model in a split plot design was used to perform the statistical analysis. The main plot was composed of four treatments (degreening and non-degreening followed by refrigerated or ambient storage), while the subplot included six storage durations $(0,2,6,10,14$, and 18 days). All data were subjected to analysis of variance (SISVAR 4.3). Tukey's test $(\mathrm{p} \leq 0.05)$ was used to compare treatment means when $F$ values were significant for main effects. Data were expressed as the average of thirty replications, 1 fruit equals 1 replication, for color development and weight loss treatments, while four replications were used for the remaining variables.

\section{RESULTS AND DISCUSSION}

\section{Color development}

Hue is the term used in the world of color for the classification of red, yellow, blue, etc. Values of hue angle near $90^{\circ}$ represent yellow color, while values near $120^{\circ}$ represent green color (MINOLTA, 2008). It is well established that the yellowing on citrus fruits might be accessed by changes in hue angle levels. 
A highly significant interaction between fruit exposure to ethylene and storage duration brought about changes in 'Lane late' surface color (hue angle) (Figure 1). It was observed that exposure to predetermined concentration of ethylene at ambient temperature and high relative humidity accelerated fruit yellowing and elicited further color development at both refrigerated and ambient conditions. In fact, hue angle values in fruit flavedo exposed to ethylene decreased $11 \%$, from 124 to 100; just 12 hours after the degreening treatment had been concluded. This decrease in hue angle continued over the course of storage reaching about $19 \%$ at the end of the experimental period. Temperature seemed to play a role on color development of fruit flavedo, since fruit stored at ambient condition, after exposure to ethylene, degreened at a faster rate. The changes in hue angle of control fruits were similar for both temperature storage and did not surpass $1 \%$ at the end of storage time. TIETEL et al. (2010) observed that hue angle values of about $120^{\circ}$ characterized green color, while values of about $90^{\circ}$ characterized yellow color on the flavedo of degreened 'Satsuma' mandarins.

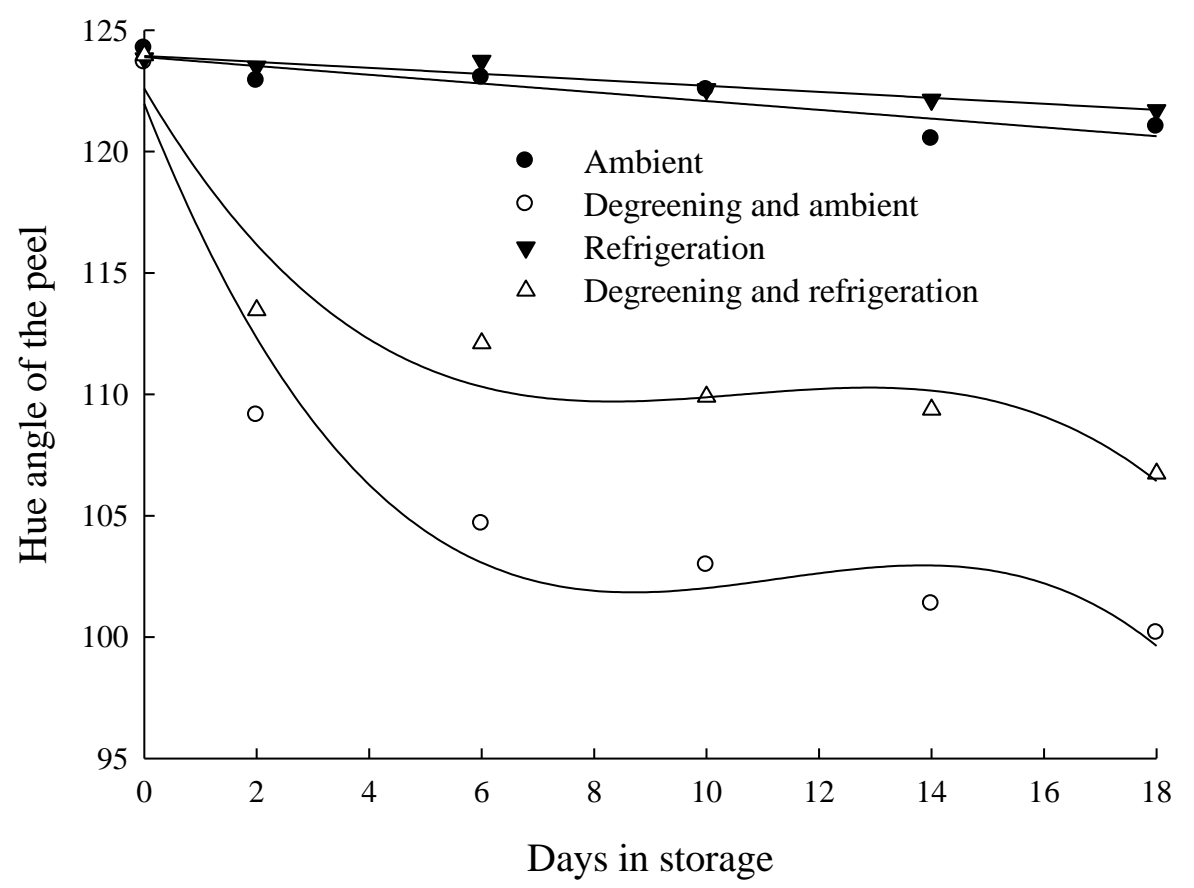

FIGURE 1. Hue angle of 'Lane late' orange degreened or not and stored under ambient $\left(24{ }^{\circ} \mathrm{C} \pm 2\right.$ and $45-50 \% \mathrm{RH})$ or refrigerated $\left(7^{\circ} \mathrm{C} \pm 1\right.$ and $\left.90 \% \pm 1 \mathrm{RH}\right)$ conditions for 18 days. ( $\mathrm{Y}$ ambient storage $=123.88-0.181 \mathrm{x}, \mathrm{R}^{2}=83.08$ ); ( $\mathrm{Y}$ degreening and ambient storage $=$ $121.97-5.85 x+0.548 x^{2}-0.0162 x^{3}, R^{2}=94.96$ ); ( $Y$ refrigerated storage $=123.94-0.123 x$, $\mathrm{R}^{2}=91.15$ ); ( $\mathrm{Y}$ degreening and refrigerated storage $=122.59-3.94 \mathrm{x}+0.389 \mathrm{x}^{2}-0.012 \mathrm{x}^{3}$, $\left.\mathrm{R}^{2}=92.83\right)$.

Chromaticity or color saturation defines color vividness, in which values near zero represent gray and dull colors. Color becomes vivid as chroma values increase toward 60. Chromaticity values of fruit flavedo exposed to ethylene increased upon fruit removal from degreening treatment, and continued to improve during storage for both storage temperatures (Figure 2). These trends are comparable to those observed above for hue angle results. Control fruit did not show significant changes in color saturation values during storage. 




FIGURE 2. Chromaticity of 'Lane late' orange degreened or not and stored under ambient $\left(24{ }^{\circ} \mathrm{C} \pm\right.$ 2 and $45-50 \% \mathrm{RH})$ or refrigerated $\left(7^{\circ} \mathrm{C} \pm 1\right.$ and $\left.90 \% \pm 1 \mathrm{RH}\right)$ conditions for 18 days. ( $\mathrm{Y}$ ambient storage $\left.=23.55+0.097 \mathrm{x}, \mathrm{R}^{2}=70.81\right)$; $(\mathrm{Y}$ degreening and ambient storage $=$ $\left.24.65+3.59 \mathrm{x}-0.361 \mathrm{x}^{2}+0.011 \mathrm{x}^{3}, \mathrm{R}^{2}=90.67\right)$; (Y refrigerated storage $=24.47+0.136 \mathrm{x}, \mathrm{R}^{2}=$ 90.16); ( $\mathrm{Y}$ degreening and refrigerated storage $=24.91+2.82 \mathrm{x}-0.268 \mathrm{x}^{2}+0.0078 \mathrm{x}^{3}$, $\left.\mathrm{R}^{2}=89.61\right)$.

Color can be divided into bright and dark tones when their lightness or brightness is compared. This brightness can be measured independently of hue angle. In a cross section diagram lightness increases toward the top and decreases toward the bottom (MINOLTA, 2008). Thus, the higher the values of lightness, the brighter the color.

Brightness of fruit flavedo exposed to ethylene and stored under refrigerated or ambient conditions increased upon fruit removal from degreening treatment and continued to increase during storage (Figure 3). Contrarily, no significant differences in brightness were observed in fruit flavedo of control from harvest to the end of storage time. 


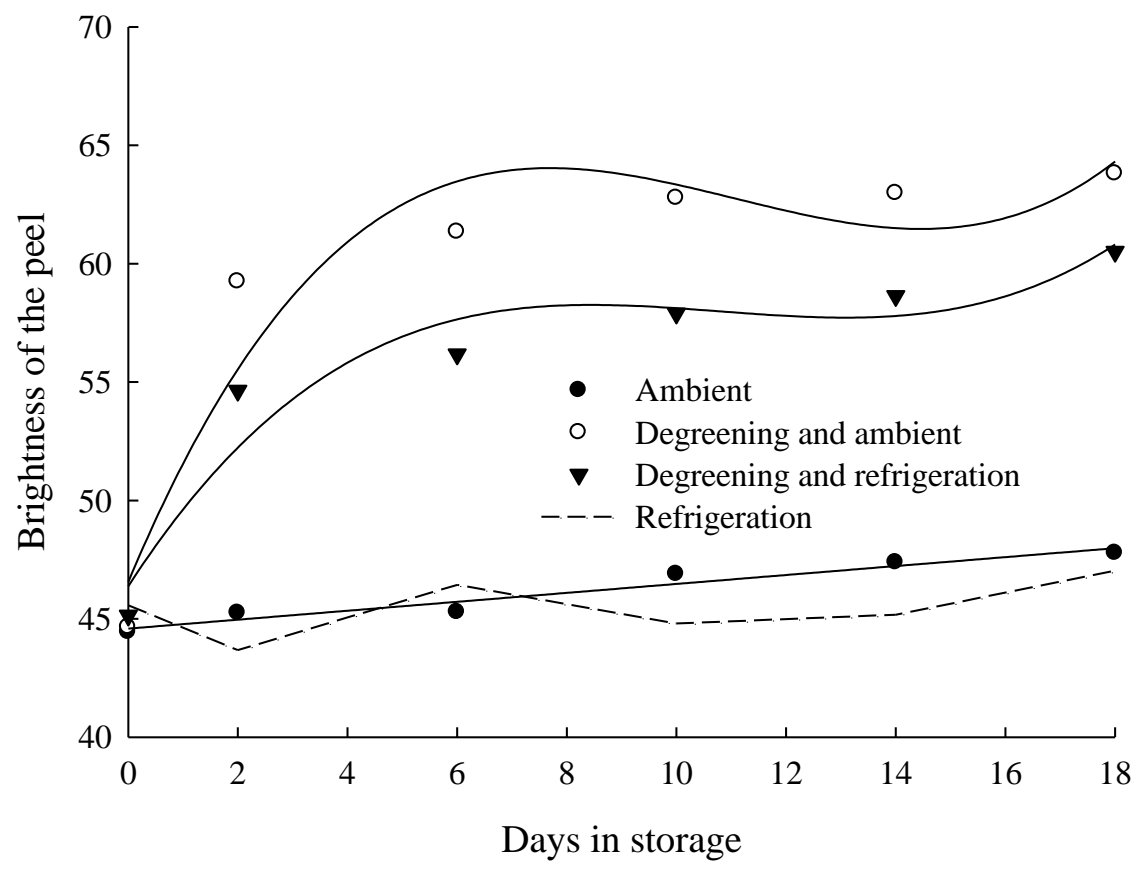

FIGURE 3. Brightness of 'Lane late' orange degreened or not and stored under ambient $\left(24^{\circ} \mathrm{C} \pm 2\right.$ and $45-50 \% \mathrm{RH})$ or refrigerated $\left(7^{\circ} \mathrm{C} \pm 1\right.$ and $\left.90 \% \pm 1 \mathrm{RH}\right)$ conditions for 18 days. ( $\mathrm{Y}$ ambient storage $\left.=44.576+0.188 \mathrm{x}, \mathrm{R}^{2}=94.81\right)$; $(\mathrm{Y}$ degreening and ambient storage $=$ $\left.46.557+5.526 \mathrm{x}-0.5505 \mathrm{x}^{2}+0.0161 \mathrm{x}^{3}, \quad \mathrm{R}^{2}=90.68\right)$; $(\mathrm{Y}$ refrigerated storage $=$ Nonsignificant, $\mathrm{R}^{2}<70$ ); ( $\mathrm{Y}$ degreening and refrigerated storage $=46.372+3.583 \mathrm{x}$ $\left.0.348 x^{2}+0.011 x^{3}, R^{2}=93.06\right)$.

Thus, as indicated by the significant decrease in hue angle values, increase in color saturation or vividness, and increase in brightness; it may be stated that the condition specified above promotes the degreening of 'Lane late' orange. It was observed that once color development is triggered by exogenous ethylene, it remains unaffected by the removal of ethylene supply, suggesting a considerable residual effect of the ethylene treatment.

These findings agree with those reported by TIETEL et al. (2010) on degreening of 'Milho' Satsuma mandarins exposed to ethylene at $4 \mu \mathrm{L} . \mathrm{L}^{-1}$ during 5 days at $30{ }^{\circ} \mathrm{C}$. These authors found decrease in hue angle (from 118 to 88), increase in lightness (from 56 to 67) and increase in color saturation (from 31 to 42), characterizing peel color change from dark green to bright yellow.

Color change on citrus fruit flavedo induced by exposure to ethylene is the result of both a coordinated degradation of chlorophylls and a simultaneous accumulation of carotenoids (RODRIGO \& ZACARIAS, 2007). According to these authors, citrus fruit exposure to predetermined ethylene concentrations may be used to reproduce and accelerate biochemical and gene expression changes that occur naturally during fruit ripening.

\section{Fruit loss of weight (\%)}

Weight loss of sweet orange cv. 'Lane late' was minor during degreening treatment as the relative humidity remained high during ethylene exposure. Relative humidity seemed to play a role on fruit loss of weight not only during fruit exposure to ethylene, but also during storage. Since fruit kept under high relative humidity, degreened or not, lost about $2 \%$ of their initial weight, while fruit kept under low relative humidity lost about 10\% (Figure 4). 


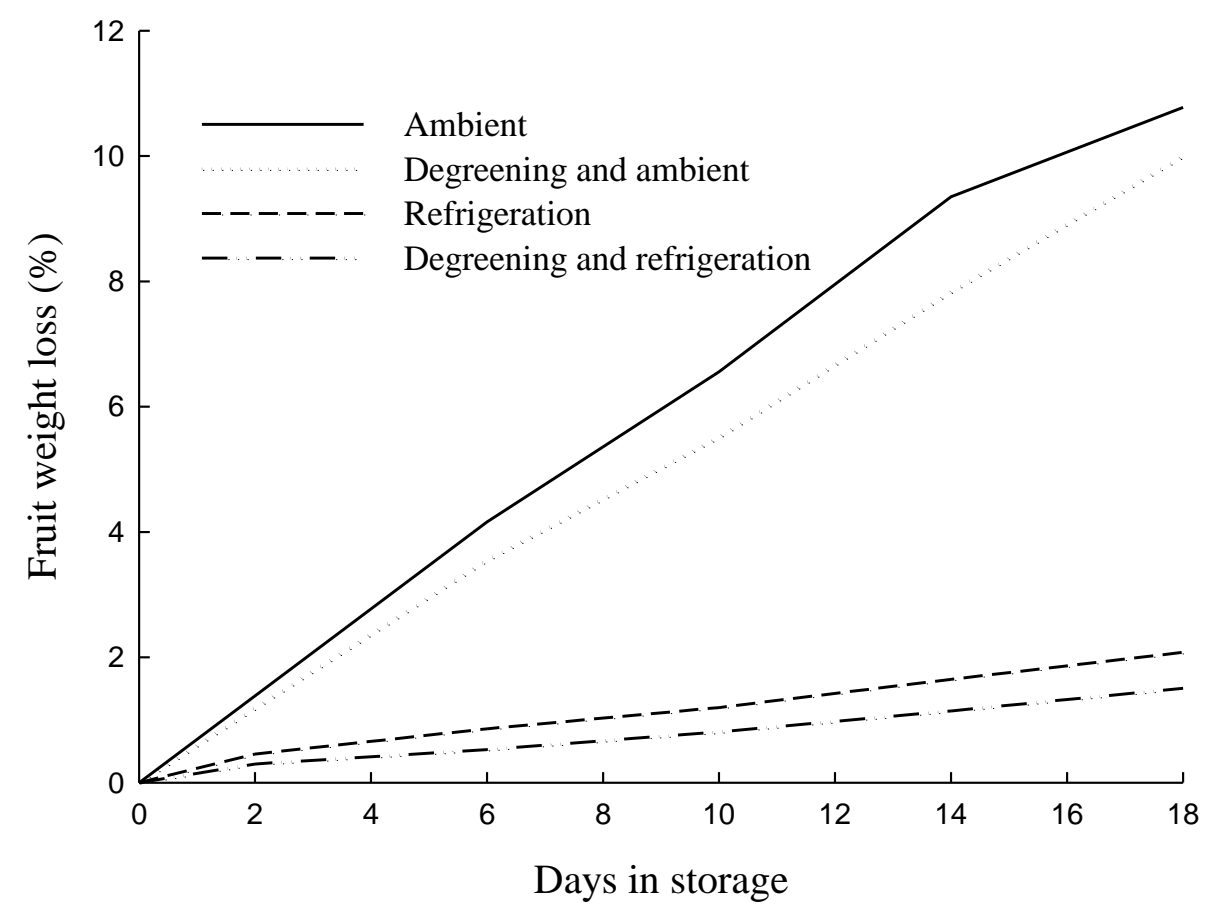

FIGURE 4. Weight loss of 'Lane late' orange degreened or not and stored under ambient $\left(24^{\circ} \mathrm{C} \pm 2\right.$ and $45 \% \pm 5 \mathrm{RH})$ or refrigerated $\left(7^{\circ} \mathrm{C} \pm 1\right.$ and $\left.90 \% \pm 1 \mathrm{RH}\right)$ conditions for 18 days.

These findings agree with previous results reported by MACHADO et al. (2010), in which loss of weight on sweet orange cv. 'Navelina' was not influenced by degreening treatment; being mainly affected by relative humidity at storage. Accordingly, SINGH \& REDDY (2006) reported that weight loss in 'Nagpur' mandarin stored under ambient temperature $\left(28{ }^{\circ} \mathrm{C}\right)$ and low relative humidity (58\%) was three-folds higher than fruit stored under refrigerated temperature $\left(7^{\circ} \mathrm{C}\right)$ and somewhat high relative humidity $(78 \%)$.

\section{Quality parameters}

Fruit soluble solids, titratable acidity and $\mathrm{pH}$ means values were $8.97{ }^{\circ} \mathrm{Brix}, 0.325 \mathrm{mg}$ citric acid/ $100 \mathrm{~g}$ juice and 4.16, respectively (Table 1). None of the se quality parameters differed from harvest to the end of the storage period. Similar to our results, PEREIRA et al. (2014) did not observe changes in soluble solids, titratable acidy, and $\mathrm{pH}$ in 'Valencia Delta' orange cultivated under the same tropical conditions $\left(5^{\circ} 11^{\prime} 38^{\prime}\right.$ ' S, 37 $52^{\circ}$ ' $\left.21^{\prime \prime} \mathrm{E}\right)$, harvested at commercial ripeness, and stored at ambient condition $\left(24^{\circ} \mathrm{C} \pm 2\right.$ and $\left.45 \% \pm 5 \mathrm{RH}\right)$ for 28 days. The degreening treatment did not affect the above-mentioned parameters. TIETEL et al. (2010) did not observe significant differences in soluble solid and acidity levels for 'Milho' Satsuma mandarins exposed to ethylene at $4 \mu \mathrm{L} . \mathrm{L}^{-1}$ for 5 days at $30^{\circ} \mathrm{C}$. Although citric acid has been reported to decrease in stored citrus fruit, being the decline due to the use of organic acids for energy production and alcoholic fermentation (LIDANIYA, 2008), trends on fruit acidity and $\mathrm{pH}$ during storage seem to depend on storage duration, and fruit genotype, among others. RAPIS ARDA et al. (2008) studying the effects of cold storage on chemical composition changes in five orange genotypes ('Tarocco Messina', 'Tarocco Meli', 'Moro', 'Ovale', and 'Valencia late') observed that acidity, as well as $\mathrm{pH}$, remained unchanged during the first 20 days ('Moro', 'Ovale', and 'Valencia late') or 40 days ('T. Messina', 'T. Meli'), to decrease ('T. Messina', 'T. Meli', Moro', and 'Ovale') or increase ('Valencia late') thereafter. 
TABLE 1. Soluble solids ( $\left.{ }^{\circ} \mathrm{Brix}\right)$, titratable acidity (mg citric acid/ $100 \mathrm{~g}$ juice), and $\mathrm{pH}$ of 'Lane late' sweet orange degreened or not and stored under ambient $\left(24{ }^{\circ} \mathrm{C} \pm 2\right.$ and $45-50 \%$ $\mathrm{RH})$ or refrigerated $\left(7^{\circ} \mathrm{C} \pm 1\right.$ and $\left.90 \% \pm 1 \mathrm{RH}\right)$ condition for 18 days.

\begin{tabular}{lccccccc}
\hline & \multicolumn{7}{c}{ Storage days } \\
\cline { 2 - 7 } Treatments & 0 & 2 & 6 & 10 & 14 & 18 \\
\hline \multirow{5}{*}{ Ambient storage } & 8.70 & 8.30 & 9.13 & 9.15 & 8.90 & 8.83 \\
Degreening and ambient & 8.70 & 9.20 & 9.15 & 9.12 & 8.90 & 9.10 \\
Refrigerated storage & 8.70 & 8.50 & 8.78 & 8.38 & 8.75 & 8.58 \\
Degreening and refrigeration & 8.70 & 8.90 & 9.92 & 8.80 & 9.10 & 9.20 \\
\hline
\end{tabular}

F Test (Treatments) NS; F Test (Storage time) NS; F Test (Stora ge time x Treatments)NS

Sd $1=17.2 \% ; \operatorname{Sd} 2=14.5 \%$

\begin{tabular}{lcccccc}
\hline & Titratable acidity (mg citric acid/100 g juice) & & \\
Ambient storage & 0.283 & 0.296 & 0.349 & 0.308 & 0.372 & 0.344 \\
Degreening and ambient & 0.283 & 0.322 & 0.349 & 0.321 & 0.348 & 0.330 \\
Refrigerated storage & 0.283 & 0.349 & 0.306 & 0.329 & 0.295 & 0.320 \\
Degreening and refrigeration & 0.283 & 0.361 & 0.342 & 0.362 & 0.339 & 0.322 \\
\hline
\end{tabular}

F Test (Treatments) NS; F Test (Storage time) NS; F Test (Storage time x Treatments)NS

$\mathrm{Sd} 1=7.3 \% ; \mathrm{Sd} 2=6.6 \%$

\begin{tabular}{lllllll}
\hline & \multicolumn{7}{c}{$\mathrm{pH}$} \\
Ambient storage & 4.21 & 4.26 & 4.02 & 4.08 & 4.25 & 4.21 \\
Degreening and ambient & 4.21 & 4.20 & 4.21 & 4.22 & 4.35 & 4.15 \\
Refrigerated storage & 4.21 & 4.06 & 4.15 & 4.28 & 4.41 & 4.07 \\
Degreening and refrigeration & 4.21 & 4.00 & 3.88 & 4.07 & 4.12 & 4.04 \\
\hline
\end{tabular}

F Test (Treatments) NS; F Test (Storage time) *; F Test (Storage time $\mathrm{x}$ Treatments)NS

$\mathrm{Sd} 1=3.9 \% ; \mathrm{Sd} 2=3.52 \%$

NS and * = Non-significant by $\mathrm{F}$ Test and significant at $1 \%$ probability, respectively.

$\mathrm{Sd}=$ standard deviation.

The ratio between total soluble solids and acidity, and puncture force averaged 28.28 and $41.84 \mathrm{~N}$, respectively (Table 2); so quality parameters above-mentioned were not affected by degreening treatments or storage durations. CARVALHO et al. (2006) studying the effects of degreening treatment on color change and quality response of 'Oronules' mandarin observed that degreening treatment did no affect quality parameters such as soluble solids, titratable acidity, and $\mathrm{pH}$. Similarly, in our results, those quality parameters remained stable during a period simulating quarantine conditions. The effects of high temperature $\left(30^{\circ} \mathrm{C}\right)$ on acidity decrease in citrus 'Nagatoyuzukichi' during degreening treatment held for 5 days was reported by YAMAUCHI et al. (2008); what was not observed in this study. That may be explained by the fact that a 24-hour fruit exposure to ethylene at $28 \pm 2{ }^{\circ} \mathrm{C}$ might be inefficient to accelerate the acid metabolism state. 
TABLE 2. Soluble solids and acidity ratio, and puncture force $(\mathrm{N})$ of 'Lane late' sweet orange degreened or not and stored under ambient $\left(24{ }^{\circ} \mathrm{C} \pm 2\right.$ and $\left.45-50 \% \mathrm{RH}\right)$ or refrigerated $\left(7^{\circ} \mathrm{C} \pm 1\right.$ and $\left.90 \% \pm 1 \mathrm{RH}\right)$ condition for 18 days.

\begin{tabular}{lccccccc}
\hline & \multicolumn{7}{c}{ Storage days } \\
\cline { 2 - 7 } Treatments & 0 & 2 & 6 & 10 & 14 & 18 \\
\hline \multirow{3}{*}{ Ambient storage } & 29.89 & 29.07 & 26.63 & 30.57 & 24.00 & 25.92 \\
Degreening and ambient & 29.89 & 29.28 & 26.58 & 28.43 & 25.74 & 27.71 \\
Refrigerated storage & 29.89 & 24.31 & 28.71 & 25.80 & 30.07 & 28.67 \\
Degreening and refrigeration & 29.89 & 25.16 & 30.15 & 24.57 & 27.26 & 28.59 \\
\hline
\end{tabular}

F Test (Treatments) NS; F Test (Storage time)NS ; F Test (Storage time x Treatments)NS

Sd $1=17.5 \% ; \operatorname{Sd} 2=15.9 \%$

\begin{tabular}{lcccccc}
\hline & \multicolumn{7}{c}{ Puncture force $(\mathrm{N})$} \\
\hline Ambient storage & 46.24 & 46.05 & 35.53 & 41.68 & 31.08 & 28.25 \\
Degreening and ambient & 46.24 & 47.54 & 44.80 & 44,36 & 34.16 & 29.87 \\
Refrigerated storage & 46.24 & 46.33 & 39.44 & 55,97 & 32.28 & 51.31 \\
Degreening and refrigeration & 46.24 & 45.41 & 44.83 & 46.58 & 36.00 & 43.96 \\
\hline
\end{tabular}

F Test (Treatments) NS; F Test (Storage time) NS ; F Test (Storage time $\mathrm{x}$ Treatments)NS

$\mathrm{Sd} 1=17.5 \% ; \mathrm{Sd} 2=15.9 \%$

NS and * = Non-significant by $\mathrm{F}$ Test and significant at $1 \%$ probability, respectively.

$\mathrm{Sd}=$ standard deviation.

\section{CONCLUSIONS}

'Lane late' orange cultivated under tropical climate conditions ( $\left.5^{\circ} 13^{\prime} \mathrm{S}, 37^{\circ} 54^{\prime} \mathrm{E}\right)$ can be degreened by fruit exposure to ethylene (at $10 \mu \mathrm{L} . \mathrm{L}^{-1}$ for 24 hours) at ambient condition $\left(28 \pm 2{ }^{\circ} \mathrm{C}\right.$ and $95 \% \mathrm{RH}$ ). Fruit exposure to ethylene (at $10 \mu \mathrm{L} . \mathrm{L}^{-1}$ for 24 hours) does not affect fruit eating quality at either refrigerated or ambient storage.

\section{ACKNOWLEDGEMENTS}

The authors thank FrutaCor Co. (Fruit Company) for fruit supply; Banco do Nordeste do Brasil - BNB (Bank of Northeastern Brazil); and Fundação Cearense de Apoio a Pesquisa FUNCAP (Foundation of Research Support of Ceará State) for granting financial support to this research.

\section{REFERENCES}

CARVALHO, C. P.; MONTERDE, A.; JÁVEGA, J. M.; S ALVADOR, A. Efecto del tratamiento de desverdización en la calidad de mandarinas 'Oronules' con vistas a la exportación a Japón. Revista Iberoamericana de Tecnología, Postcosecha. v. 7, n. 002, p.104-108, 2006.

JACOMINO, A. P.; MENDONÇA, K.; KLUGE, R. A. Armazenamento refrigerado de limões 'Siciliano' tratados com etileno. Revista Brasileira de Fruticultura, Jaboticabal, v. 25, n. 1, p. 45-48, 2003.

LIDANIYA, M. S. Citrus fruit: biology, technology and evolution. San Diego: Academic Press, 2008. p. 1-558.

MACHADO, F. L. C.; COSTA, J. M. C.; CAJAZEIRAS, J. P. DA SILVA, J. P. DOS SANTOS, D. O. Desverdecimento em laranja doce 'Navelina' [Citrus sinen sis (L.) Osbeck] produzida no Baixo Jaguaribe, Estado do Ceará. In: CONGRESSO BRASILEIRO DE FRUTICULTURA. FRUTAS: SAÚDE, INOVAÇÃO E RESPONSABILIDADE, 2010, 21., Natal. Anais. . . Natal: Associação Brasileira de Fruticultura, 2010. 1 CD-ROM. 
McGUIRE, R.G. Reporting of objective colour measurements. HortScience, Alexandria, v.27, p.1254-1255. 1992.

MINOLTA Co,. Ltd. Precise color communication: color control from feeling to instrumentation. New Jersey: Williams Drive, 2008. p. 1-49.

PEREIRA, G. da S.; MACHADO, F.L.C.; COSTA, J.M.C. Aplicação de recobrimento prolonga a qualidade pós-colheita de laranja 'Valência Delta' durante armazenamento ambiente. Revista Ciência Agronômica, Fortaleza, v. 45, n. 3, p. 520-527, 2014.

PORAT, R. Degreening of citrus fruit. Tree and Forestry Science and Biotechnology. v. 2, p.71-76, 2008.

RAPIS ARDA, P.; LO BIANCO, M.; PANNUZZO, P.; TIMPANARO, N. Effect of cold storage on vitamin $\mathrm{C}$, phenolics and antioxidant activity of five orange genotypes [Citrus sinensis (L.) Osbeck]. Postharvest Biology and Technology, Amsterdam, v. 49, p.348-354, 2008.

RODRIGO, M., J.; ZACARIAS, L. Effect of postharvest ethylene treatment on carotenoid accumulation and the expression of carotenoid biosynthetic genes in the flavedo of orange (Citrus sinensis L. Osbeck) fruit. Postharvest Biology and Technology, Amsterdam, v. 43, p.14-22, 2007.

SINGH , K. K.; REDDY, B. S. Post-harvest physico-mechanical properties of orange peel and fruit. Journal of Food Engineering, Essex, v.73, p.112-120, 2006.

TIETEL, Z; WEISS, B.; LEWINSOHN, E.; FALLIK, E.; PORAT, R. Improving taste and peel color of early-season Satsuma mandarins by combining high-temperature conditioning and degreening treatments. Postharvest Biology and Technology, Amsterdam, v. 57, p. 1-5, 2010.

YAMAUCHI, N.; TOKUHARA, Y.; OHYAMA, Y.; SHYGYO, M. Inhibitory effect of sucrose laurate ester on degreening in Citrus nagato-yuzukichi fruit during storage. Postharvest Biology and Technology. Amsterdam, v. 47, p. 333-337, 2008. 